\title{
The ranking of insurance companies from Romania based on multicriterial analysis
}

\section{Gabriela Bilevsky}

Institute for Economic Forecasting, Romanian Academy

050711, Bucharest - Romania, Casa Academiei, Calea 13 Septembrie nr.13, sector 5

PhD Student

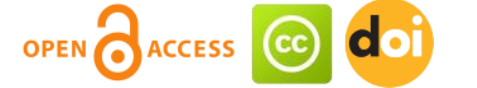

Article history:

Received: January 18, 2017

1st Revision: February 8, 2018

Accepted: March 17, 2018

JEL classification:
G32
G22
G33
G19

DOI:

10.14254/jems.2018.3-1.9

\begin{abstract}
The article is based on a wider study conducted by the author, on a sample of 10 of the most long-lived insurance companies, with different levels of gross premiums charged, activating on the Romanian insurance market. Starting with a multicriterial analysis, which showcases these companies' bankruptcy risk in 2016, the author used the ranking method and the relative distance method. These methods allow the investigation and integration of several economic agents' interests, considering qualitative and quantitative information for each company as criteria. The analysis provides a ranking of the companies according to several criteria taken simultaneously, which leads to an improvement in the quality of decision-making.
\end{abstract}

Keywords: Bankruptcy risk, insurance, multicriterial analysis, sustainable development.

\section{Introduction}

The risks to which companies are subjected are numerous, and among them the strongest impact on their activity is bankruptcy risk, which arises when a company defaults, which is closely linked to insolvency (Bilevsky, 2013).

The literature on risk analysis showcases three large groups of methods, namely: qualitative, used in conditions of low risk (Brainstorming, questionnaires and structured interviewing, assessment for multidisciplinary groups and the Delphi Technique); semi-quantitative, used in high/medium/low-type classifications or more detailed descriptions of probabilities or consequences, and quantitative, which allow the assignment of values for the incidence of the various identified risks, that is, the calculation of the risk level, the best known being the Monte Carlo method that aims to represent reality by means of a mathematical risk model, so that by assigning random values to the model, different scenarios and results are obtained( see IsaicManiu, 2006). In this respect, scoring models, discriminatory methods, and complex econometric models have been developed that provide the possibility of choosing the best alternatives for determining bankruptcy risk. Romania too has specialists who have experimented with the scores method, building bankruptcy prediction models (Dragotă et all, 2012; Anghel, 2002; Băileșteanu, 1998; Vâlceanu, 2005). 
The Romanian insurance market is regulated; according to law, it is divided into two major categories: general insurance and life insurance. One of the most important indicators of the insurance market is the gross revenue registered by the insurance companies after the conclusion of contracts, and they are represented by the gross written premiums. The insurance activity carried out after Romania's accession to the EU has experienced a marked fluctuation, which resulted in the massive increase or decrease of revenue from gross written premiums (Deakin, 1972).

Starting with 2015 there has been an upward trend of gross written premiums in the total insurance market, with nominal values rising from Ron 8.7 billion in 2015 to Ron 10.5 billion in 2017, the highest increase taking place in 2016 (from 16.09\% compared to 2015). This trend is sustained in particular by the maintenance in the growth of gross written premiums from life insurance, with a segment consolidation in 2017 and revenues up to Ron 2.5 billion, the highest value on the studied period.

\section{Methodology}

Multicriterial analysis is a type of analysis based on multiple criteria, being a decision-making method for addressing complex issues involving a high degree of uncertainty over a general class of operations. The research systems (Wang et al, 2009) approached are in line with modern techniques and are different from other common methods used in this type of analysis.

There are four initial reasons (Tsoutos et al, 2009) that justify the use of multicriterial decision-making methods:

1. They allow the investigation and integration of the interests and objectives of several economic agents, given that both the quantitative and the qualitative information of each company is taken into account as criteria and weight factors;

2. The criteria and objectives are chosen by mutual agreement and may be modified during the analysis if they are found to be inadequate to the specific issues, based on the performances established by experts;

3. The explicit format of the result, which is significant and directly applicable by providing output information that is easy to communicate to interested companies;

4. It is a method that allows objectivity and inclusion of the decision maker's different perceptions and interests without additional costs.

The results obtained by applying this method, such as scores and weighted average values, can also be used for auditing. They provide a better understanding of the inherent characteristics of the decision-making issue, promote the participants' role in the decision-making processes, facilitate compromise and collective decisions, and provide a basis for understanding the models and analysts' point of view. The purpose of applying these methods contributes to the quality of the decisions taken, making them more explicit, more rational and more effective. Negotiation, quantification and communication of priorities are also facilitated by the use of these methods.

These multicriterial methods of analysis generate a hierarchy that is used specifically for company rankings, to detect the differentiated levels on which they are placed. At this stage, the most satisfactory and effective solution for the development of medium- or low-level development companies is sought.

The need to classify alternatives in the final decision generates the application of a multicriterial method. The key factors for the decision-makers in selecting multicriterial methods are the degree of uncertainty and the data they have at the time of analysis.

The most common ranking methods include: the real ranking method, the relative distance method, the rank sum method, the uniformly increasing ranks method, matrix methods.

Compared to the other methods, there are some differences in the approach of the real ranking method, which represent elements of originality within the article:

- Between the individual values of the studied indicators there are certain relative distances taken into account in the analysis;

- Based on the different importance of the indicators used in the analysis, the higher weights are assigned to indicators relevant from an information standpoint (e.g. average income, gross domestic product per capita, etc.).

Where multicriterial analysis is used as the decision-making method, the results obtained by measuring attributes using different scales are only used if they are converted into comparable values. For this, the criteria chosen must contain identical scorecards in order to be combined. With the help of a value function, specific scores can be converted into comparable criteria scores. This represents their normalization or standardization.

Next, we will present two of the most common multicriterial ranking methods: the ranking method and the relative distance method. 
a) Ranking method

The steps to be followed in applying the ranking method are:

1. Each company is assigned a rank for each economic indicator studied, rank 1 being attributed to the company with the best performance;

2. The ranks obtained by each company are aggregated and a score is obtained for that company;

3. Finally, the lowest bankruptcy risk is represented by rank 1, assigned to the company with the lowest score.

As opposed to the ranking method, the method of relative distance to the minimum / maximum performance sets as the company with the highest risk of bankruptcy as the benchmark.

\section{b) Relative distance method}

The company with the lowest score, therefore with the lowest risk of bankruptcy, is considered the benchmark. Then the distance from the company with the lowest bankruptcy risk to each of the other companies is calculated for every indicator. This distance is a relative measure of coordination.

In order to determine the average relative distance for each insurance company, the geometric mean of each company's distance from the benchmark is calculated.

Final ranks are received based on the increasing values of the average relative distances. Rank 1 is assigned to the company with the lowest relative average distance, and which represents the company with the highest risk of bankruptcy.

The relative average distance compared to the maximum value of the relative average distance determines the companies' rank as compared to the best performing company.

\section{Methods of multicriterial ranking for purposes of drawing up a ranking of insurance companies based on bankruptcy risk}

Statistical methods of multicriterial ranking (ranking and relative distance to the company with the lowest bankruptcy risk) provide a classification of units according to several criteria calculated simultaneously. The following indicators will be taken into account in drawing up the 2016 insurance companies ranking:

- Total assets(I1);

- Subscribed called up capital (I2);

- Gross Claims paid (I3);

- Gross Written Premiums (I4);

- Profit/ loss for the period (I5);

- Total technical reserves (I6).

The analysis uses 10 insurance companies:

- ABC Asigurări (S1);

- ALLIANZ-TIRIAC (S2);

- ASIROM VIG(S3);

- Asito Kapital (S4);

- Carpatica (S5);

- City Insurrance (S6);

- Garanta (S7);

- Generali (S8);

- Omniasig VIG (S9);

- Uniqa Asigurări (S10)

The ranking method consists in the following steps:

a. A rank is assigned to each value of the economic indicator analyzed for each company (the value associated to the best performance is ranked 1);

The rank is marked with $\left(r_{i_{i n d_{j}}}\right), i=1,2, \ldots, 10$ and the economic indicator, with $i n d_{j}, j=$ $1,2, \ldots, 6$.

Except for gross claims paid, the higher the other indicators, the better the company's performance. 
b. All the values assigned to the economic indicator are summed up for each company, and a score is calculated according to the formula: $S_{i=\sum_{j=1}^{6}\left(r_{i_{i n d}}\right)}, i=1,2, \ldots, 10$

c. The company with the lowest score has the lowest bankruptcy risk and is ranked 1 . The results of the method are summarized in Table 1.

\begin{tabular}{|c|c|c|c|c|c|c|c|c|c|c|}
\hline $\begin{array}{l}\text { Economic } \\
\text { Indicator }\end{array}$ & $\begin{array}{c}\text { Rank } \\
\text { S1 }\end{array}$ & $\begin{array}{c}\text { Rank } \\
\text { S2 }\end{array}$ & $\begin{array}{c}\text { Rank } \\
\text { S3 }\end{array}$ & $\begin{array}{c}\text { Rank } \\
\text { S4 }\end{array}$ & $\begin{array}{c}\text { Rank } \\
\text { S5 }\end{array}$ & $\begin{array}{c}\text { Rank } \\
\text { S6 }\end{array}$ & $\begin{array}{c}\text { Rank } \\
\text { S7 }\end{array}$ & $\begin{array}{c}\text { Rank } \\
\text { S8 }\end{array}$ & $\begin{array}{c}\text { Rank } \\
\text { S9 }\end{array}$ & $\begin{array}{c}\text { Rank } \\
\text { S10 }\end{array}$ \\
\hline I1 & 9 & 2 & 3 & 8 & 10 & 5 & 7 & 4 & 1 & 6 \\
\hline I2 & 9 & 5 & 2 & 8 & 10 & 6 & 7 & 4 & 1 & 3 \\
\hline I3 & 2 & 9 & 8 & 1 & 5 & 7 & 3 & 4 & 10 & 6 \\
\hline I4 & 9 & 1 & 3 & 10 & 7 & 4 & 8 & 5 & 2 & 6 \\
\hline I5 & 5 & 1 & 3 & 9 & 6 & 10 & 8 & 2 & 4 & 7 \\
\hline I6 & 8 & 1 & 3 & 9 & 10 & 5 & 7 & 4 & 2 & 6 \\
\hline Sum of ranks & 42 & 19 & 22 & 45 & 48 & 37 & 40 & 23 & 20 & 34 \\
\hline Final Rank & 8 & 1 & 3 & 9 & 10 & 6 & 7 & 4 & 2 & 5 \\
\hline
\end{tabular}

Note: rank 1 for the smallest bankruptcy risk

Source: own results

According to the ranking method, the lowest bankruptcy risk in 2016 was Allianz-Ţiriac, followed by Omniasig and Asirom. Carpatica showed the highest risk, and this company's bankruptcy was actually decided in court in early 2017. It is followed by Asito Kapital, a small company that did not meet the minimum conditions of solvency according to the Solvency I supervisory regime, or the minimum capital condition according to the Solvency II supervisory regime, but which increased its capital in two stages, reaching Ron 20.6 million in 2016. In these new financial coordinates, the Solvency II conditions are met, with a MCR of Ron 17 million and a SCR of Ron 19.8 million - the company thus survived on the market.

The method of relative distance from the company with the lowest bankruptcy risk involves calculating every company's distance to the one with the lowest bankruptcy risk for each economic indicator. The distance is determined as a relative coordination measure:

$$
d_{i_{\text {ind }}}=\frac{\operatorname{ind}_{i}^{j}}{\left\{\text { optimabs }\left(\text { ind } d_{i}^{j}\right\}_{i=1,2}\right.}, i=1,2, \ldots, 10 \text { and } j=1,2, . ., 6
$$

The geometric mean for the distances of each insurance company is determined, signifying the relative average distance for the insurance company $i$.

$$
\overline{d_{i}}=\sqrt[6]{\prod_{j=1}^{6} d_{i_{\text {ind }}}}, \mathrm{i}=1,2, \ldots, 10
$$

The final ranks are assigned according to the values of the relative average distance values. The company with the lowest relative average distance is ranked 1 and is the one with the highest risk of bankruptcy.

Each company's ranking relative to the best performance is given by the ratio between the relative average distance and the maximum value of the relative average distance:

$$
\operatorname{position}_{i}^{\%}=\frac{\bar{d}_{l}}{\max \left(\bar{d}_{l}\right)_{i=\overline{1,10}}} \cdot 100
$$

The results turned by this method for the 10 insurance companies selected in 2016 are summarized in Table 2. 


\begin{tabular}{|c|c|c|c|c|c|c|c|c|c|c|}
\hline $\begin{array}{l}\text { Economic } \\
\text { indicator }\end{array}$ & S1 & S2 & S3 & S4 & S5 & S6 & S7 & S8 & S9 & S10 \\
\hline I1 & 0.0164 & 0.9506 & 0.8129 & 0.0267 & 0.0014 & 0.5225 & 0.0566 & 0.5656 & 1.0000 & 0.4765 \\
\hline $\mathrm{I} 2$ & 0.0426 & 0.2035 & 0.9162 & 0.0445 & 0.0017 & 0.2011 & 0.0607 & 0.3859 & 1.0000 & 0.6681 \\
\hline I3 & 1.6130 & 72.3785 & 65.3530 & 1.0000 & 36.6010 & 54.3074 & 1.6820 & 32.4761 & 88.8375 & 39.9162 \\
\hline I5 & 0.0083 & 1.0000 & 0.3553 & 0.0144 & 0.0025 & 0.4034 & 0.0005 & 0.7225 & 0.0094 & 0.0016 \\
\hline I6 & 0.0130 & 1.0000 & 0.7782 & 0.0121 & 0.0001 & 0.4996 & 0.0437 & 0.5993 & 0.8280 & 0.4596 \\
\hline $\begin{array}{l}\text { Average } \\
\text { relative } \\
\text { distance }\end{array}$ & 0.0371 & 1.5525 & 1.5079 & 0.0373 & 0.0143 & 0.9511 & 0.0401 & 1.0823 & 0.9217 & 0.3915 \\
\hline
\end{tabular}

Note: rank 1 for the highest bankruptcy risk

Source: own results

According to the distance method, the lowest risk of bankruptcy in 2016 was Allianz, followed by Asirom and Generali. The highest risk of bankruptcy was Carpatica, which actually went bankrupt. ABC Asigurari and AsitoKapital also showed a high risk of bankruptcy. We can see here that both methods show that Allianz Tiriac has the lowest risk of bankruptcy, while Carpatica is the most vulnerable from this point of view.

\section{Conclusions}

Unlike other studies from the relevant literature, this article attempts a ranking of 10 Romanian insurance companies based on multicriterial ranking methods for 2016. These methods take into account the performance of several indicators simultaneously.

Based on the multicriterial analysis, a ranking of 10 insurance companies is carried out for 2016, namely: ABC Asigurări (S1); Allianz(S2); Asirom (S3); Asito Kapital (S4); Carpatica (S5); City Insurance (S6); Garanta (S7); Generali (S8);Omniasig VIG (S9); Uniqa Asigurări SA (S10).

Two methods were used alternately: the ranking method, and the relative distance method. What is significant is that the use of different methods led to the same result for the company with the lowest bankruptcy risk: Allianz-Tiriac. The results differ for the companies ranked second and third in terms of bankruptcy risk in 2016, the explanation deriving from the calculation method and the limitations of the methods that took only one year into consideration. Surprisingly, the analyses did not reveal any risks for Asirom, which actually entered insolvency, despite the fact that the ranking method based on specific indicators did not return this possibility. One explanation may be that insolvency was also linked to investigations into a series of irregularities in this company, reported by the financial supervisory bodies. However, Asirom changed its financial conditions within the limits imposed by the Solvency II regime in 2017, surviving on the market with full prerogatives.

\section{Appendix A. Supplementary material}

Supplementary data associated with this article can be found, in the online version, at https://doi.org/10.14254/jems.2018.3-1.9.

\section{Funding}

The authors received no direct funding for this research.

\section{Citation information}

Bilevsky, G. (2018). The ranking of insurance companies from Romania based on multicriterial analysis. Economics, Management and Sustainability, 3(1), 94-100. doi:10.14254/jems.2018.3-1.9. 


\section{References}

ABC Asigurări. (2016). Raportul anual 2016. Retrieved from http://www.abcasigurari.ro/abc1/images/resurse_abc/raport_anual_2016.pdf

Allianz Tiriac Asigurări S.A. (2016). Raport privind Solvabilitatea ș iSituația Financiară 2016, Retrieved from https://www.allianztiriac.ro/v_1500328800000/documents/rapoarteanuale/Raport_privind_solvabilitatea_si_situatia_financiara_-_Allianz_Tiriac_Asigurari_SA.pdf

Anghel, I. (2002). Bankruptcy Radiography and Predilection. Economic Publishing House, Bucureşti.

Asirom (Societatea Asigurarea Românească Asirom - Vienna Insurance Group S.A) (n.d.). Retrieved from https://www.asirom.ro

Asirom Vienna Insurance Group S.A. (2016). Raport privind Solvabilitatea și Situația Financiară, Asirom - Vienna Insurance Group S.A 2016. Retrieved from https://www.asirom.ro/resources/user_doc/ASIROM\%20SFCR\%2031.12.2016.pdf

Asito Kapital. (2016). Raport annual AsitoKapital 2016. Retrieved from https://docs.wixstatic.com/ugd/9c1c79_bd5aa6bec91b43de9a2089ca8b160b7d.pdf

Asito Kapital. (n.d.). Retrieved from https://www.asitokapital.com/

Băileșteanu, Gh. (1998). Diagnosis, Risk and Efficiency in Business. Mirton Publishing House, Timișoara.

Bilevsky, G. (2013). Tools and methods to prevent the risk of bankruptcy of the insurance companies. Internal Auditing \& Risk Management, VIII, 3 (31), 79-88. Retrieved from https://ideas.repec.org/a/ath/journl/v31y2013i1p79-88.html

City Insurance. (2016). Raport privind solvabilitatea si situatia financiara 2016. Retrieved from https://cityinsurance.ro/default/raport-privind-solvabilitatea-si-situatia-financiara/

Deakin, E. B. (1972). A discriminant analysis of predictors of business failure. Journal of accounting research, 167-179.

Decision 1498/27.07.2016. (n.d.). The Financial Supervisory Authority. Retrieved from https://asfromania.ro/consumatori/informatii-carpatica/informatii-carpatica

Dragotă, V., Obreja-Braşoveanu, L., \& Dragotă, I.M. (2012). Management financiar, ediţia a doua. Vol I, Diagnosticul financiar al companiei, Editura Economică, București,

Garanta Asigurari. (2016). Raport privind Solvabilitatea și Situația Financiară 2016. Retrieved from https://www.garanta.ro/pdf/Rapoarte_RO/Raport_privind_Solvabilitatea_si_Situatia_Financ iara_pentru_anul_2016_21_IULIE.pdf

Generali Asigurări. (2016). Raport privind Solvabilitatea și Situația Financiară 2016. Retrieved from https://www.generali.ro/wp-content/uploads/2017/01/Raport-Solvabilitate-si-Situatiefinanciara.pdf.

Isaic-Maniu, I. (2006). Caracterizarea statistică a riscului - Concepte, tehnici, aplicaţii. Publisher ASE, București.

Omniasig Vienna Insurance Group S.A. (2016). Raport privind Situația Financiară și Solvabilitatea 2016. Retrieved from https://www.omniasig.ro/resources/user_doc/Raport\%20SFCR_2016.pdf

Romanian Financial Supervisory Authority. (2016). Annual Report 2016. Retrieved from https://asfromania.ro/en/publications/annual-report/asf-annual-report

Teodorescu, S. (2010). Fundamentele asigurărilor. Editura Bren, București.

Tsoutsos, T., Drandaki, M., Frantzeskaki, N., Iosifidis, E., \& Kiosses, I. (2009). Sustainable energy planning by using multi-criteria analysis application in the island of Crete. Energy Policy, 37(5), 1587-1600. doi:10.1016/j.enpol.2008.12.011

UniqaAsigurări S.A. (2016). Raport privind solvabilitatea si situatia financiara. Retrieved from https://www.uniqa.ro/documents/Uniqa_Asigurari_Raport_privind_Solvabilitatea_si_Situati a_Financiara.pdf 
Vâlceanu, Gh., Robu, V., \& Georgescu, N. (2005). Economic-Financial Analysis. Economic Publishing House, București.

Wang, J. J., Jing, Y. Y., Zhang, C. F., \& Zhao, J. H. (2009). Review on multi-criteria decision analysis aid in sustainable energy decision-making. Renewable and Sustainable Energy Reviews, 13(9), 2263-2278.

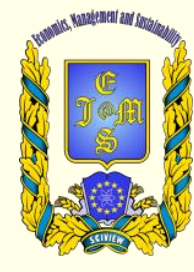

() 2016-2018, Economics, Management and Sustainability. All rights reserved.

This open access article is distributed under a Creative Commons Attribution (CC-BY) 4.0 license.

You are free to:

Share - copy and redistribute the material in any medium or format Adapt - remix, transform, and build upon the material for any purpose, even commercially.

The licensor cannot revoke these freedoms as long as you follow the license terms.

Under the following terms:

Attribution - You must give appropriate credit, provide a link to the license, and indicate if changes were made.

You may do so in any reasonable manner, but not in any way that suggests the licensor endorses you or your use.

No additional restrictions

You may not apply legal terms or technological measures that legally restrict others from doing anything the license permits.

Economics, Management and Sustainability (ISSN: 2520-6303) is published by Scientific Publishing House "CSR", Poland, EU and Scientific Publishing House "SciView", Poland

Publishing with JEMS ensures:

- Immediate universal access to your article on publication

High visibility and discoverability via the JEMS website

Rapid publication

- Guaranteed legacy preservation of your article

- Discounts and waivers for authors in developing regions

Submit your manuscript to a JEMS at http://jems.sciview.net or submit.jems@sciview.net

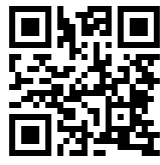

